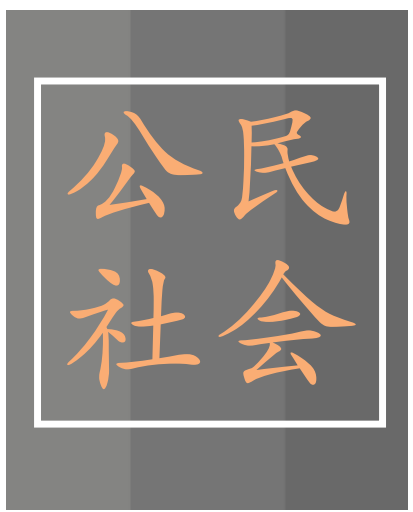

公民社会 (gongmin shehui, literally 'citizen society').

\section{Painting in Grey and Permeating Gaps Changing the Space for Chinese NGOs}

Holly SNAPE

6 peak this clearly: the development goal for Chinese society is a Marxist social community; it is not a Western civil society of state-society opposition.' This comes from a recent article originally published on the public WeChat account of a central academy (CPPCC Daily 2019). The academy is charged with training people from the 'democratic parties', religious groups, and ethnic minorities. When referring to civil society, the article uses the slightly less sensitive term 市民社会 (shimin shehui, literally 'townspeople society') and not 公民社会 (gongmin shehui, literally 'citizen society'), sidestepping the problem of clarifying its position on something that is all but unspeakable. Over a number of years, the term gongmin shehui has been gradually blotted out of the public lexicon (Bandurski 2011). CNKI, a Chinese academic database, shows a peak of papers with this term in the title in the period between 2009 and 2011. This fell off sharply from 2012 to 2015 , and by 2018 research overtly discussing civil society using this term had been almost entirely expunged. Shimin shehui is now following a similar trajectory.

'Civil society' is not the only casualty of this lexical cleansing. A whole family of related vocabulary is being polished and trimmed. After almost two decades as the 'NGO Research Centre' (NGO研究所), Tsinghua University's cuttingedge research institute quietly changed its name to the 'Social Organisation and Social Governance Research Centre' (社会组 织与社会治理研究所). The popular term 'public interest' (公 益), used to express a panoply of citizen-led activity, seems to be undergoing a similar process. It is being uncluttered of its potential connotations of citizens' rights, a public sphere, and anything conceivably 'oppositional', and is instead being affixed to the more congenial term 'charity' (慈善). It now appears often in the neat compound 'public interest-cum-charity' (公益慈善). This is not just a matter of abstract ideas. It is a process of shaping the space to conceive of real activities and possibilities. This possibility-shaping, combined with a process of government institution-building and Party permeation, is slowly but deeply changing citizen organising in China. 
Before 2016, when the country's first Charity Law went into force, for around three decades there was an enormous amount of citizenled organising at the grassroots. It happened in a regulatory grey zone.
The past three years have seen the beginning of a gradual shift in what is usefully conceptualised in scholarship as 'grey space' (Yang 2005). Before 2016, when the country's first Charity Law went into force, for around three decades there was an enormous amount of citizen-led organising at the grassroots. It happened in a regulatory grey zone. Technically, most types of 'social organisation'-essentially non-governmental organisations (NGOs), though the official lexicon smoothed this term away too-were obliged to register with the government, usually after finding a sponsoring agency to add a second layer of management. If NGOs did not register, they could be deemed illegal and shut down. Yet, over the decades the government departments charged with enforcing the regulations did so only selectively, in fits and starts, or not at all. This enabled citizens to establish grassroots NGOs numbering in the hundreds of thousands, if not upwards of a million (Deng 2010). These unregistered organisations were an important focus of legislators in developing the Charity Law (Zheng 2016), the beginning of a trickle of legislation and institution-building that is reshaping the space for NGOs to exist and operate.

On paper, this legislation largely eliminates the grey space (Teets and Almen 2018). It creates detailed legal obligations and duties for both governments and NGOs regarding registration, internal governance, regulation, and oversight. But, most importantly, enforcement has not been approached in such a way as to erase all grey space instantly. Instead, so far there has been a prolonged process of disappearing space, enabling an uncertain grace period for NGOs to choose whether to comply or gradually crumble. This has been achieved through a combination of temperately-paced institution-buildingcreating incentives and compulsion-and the increasingly explicit verbal and written commands of government and Party. Some moves are more sudden while others are slow, creating heightened uncertainty for all those NGOs that remain in the process of adjustment.

New forms of e-governance are creating pressure to comply and conform or be caught out, shamed, or closed down. In June this year, the Ministry of Civil Affairs released an app directly accessible on WeChat that allows users to check instantly the legal status and basic data of any Chinese NGO just by searching its name. This shifts part of the burden of enforcement from government to citizens, who can now call out any organisation that has not registered. Central and local government departments have also used online platforms to sporadically release blacklists of law-breaking or 'fake' NGOs, presumably with the intention of pressing others to comply and build awareness of the notion of 'illegal social organisations'. 
None of these

developments amount

to an instant push to close down NGOs that

do not immediately comply with legislation; what they do, instead, is create pockets of transparency and the haunting possibility of being 'found out'.
Some localities have begun using platforms like WeChat public accounts and online news agencies to encourage compliance with detailed regulations. A notable example is the shaming of NGOs that have failed to comply with requirements about reporting for government approval on activities such as leadership changes and anything involving foreign people or money. None of these developments amount to an instant push to close down NGOs that do not immediately comply with legislation; what they do, instead, is create pockets of transparency and the haunting possibility of being 'found out'.

The widely propagated speeches of government and Party leaders act as authoritative interpretations regarding what 'social organisations' should be and do, what their ultimate purpose is, and how 'charity' should be understood.

An article written by Zhan Chengfu, the Vice-minister of Civil Affairs and person directly in charge of 'managing' NGOs, offers a window onto the thinking guiding decisionmaking throughout the civil affairs system. Zhan argues that the time has come to make clear what it means to develop a 'path with Chinese characteristics for social organisation development' (Zhan 2016). He directly refutes any notion that Party leadership over NGOs-which he never names as such-conflicts with the right of association that appears in the country's Constitution. He stresses that over many years, while 'a vast number of "Western" essays and books on "NGOs", "non-profit organisations", and the "third sector" have been translated into Chinese, read, and accepted, "efforts to build our own social organisation culture, social organisation value system, and discourse have been left behind' (Zhan 2016,17). What Zhan means by 'our own' is quite clear: he states that when government and Party organisations approve an NGO's 'entrance' into the sphere of legality, revoke its registration, or ban it altogether, decisions should be based on 'whether that NGO is conducive to maintaining the Party's governing status, to expanding the base from which the Party governs, and to accomplishing the Party's governing mission' (Zhan 2016, 17).

Why should we care about the speeches and articles of officials in the civil affairs system? First, their interpretations give greater shape and clarity-for those making, implementing, and being targeted by policy-to principles and concepts that remain open to interpretation.

Second, they signal that in the 'new era' the 'lawlessness' of the past will not stand, perhaps with the caveat that there is still enough grey space for the process described above. Zhan has made 'no land beyond the law' (没有法外之地) a repeated motif 
in his speeches to actors like charities, alliances, corporations, and banks. For example, during a speech at the Internet Public Interest Forum, held in Guangzhou in May 2019, he told his audience: 'If you become more charity-conscious and respect the Charity Law's authority, remaining within the scope set out in the charity [regulatory] system, you will neither "overstep" or "understep" the mark' (Public Interest Daily 2019). He them that 'all means involving looking for loopholes and exploiting weaknesses are in the spirit of rule-of-law-violation'. His speech stressed that while some issues are not covered by the Charity Law, actors should go by the 'original meaning of the legislation’ (立法的本意) when determining how to behave. This places the onus on actors to heed the words of individual leaders to understand that 'meaning'.

Third, it is in the interest of local officials to ensure implementation of policy and legislation in line with the preferences of the top leadership. Civil servants at every level throughout the civil affairs system nationwide are subject to new political demands institutionalised through an amended Civil Servants Law passed in 2018. They will now be assessed on their 'political quality' (政治素质) as much as on their 'work achievements' (工作实绩) - a fundamental change in their incentive structures. Meanwhile, leading Party cadres in the civil affairs system are also affected by new Party regulations. For instance, while the minister and vice-ministers are, as civil servants, managed by the new Civil Servants Law; as members of the Ministry's Party Group (党组), they are also managed by a new set of regulations on Party groups, issued in 2015, amended in 2019, and otherwise unprecedented in the 70 years that Party groups have existed in the Chinese Communist Party (CCP). The obligations and accountability of these Party group members regarding Party leadership in their respective roles have thus been made concrete.

Along with these inseparable processes of possibilityshaping, institution-building, and authoritative interpretation is another trend of deep significance to civic space. We might for now call it 'Party permeation'. The phenomenon of the CCP seeking to lead all activities is, itself, not new. It was described to me recently as 'pouring mercury the length of the land' (水 银泻地), or ensuring there is no space without the glimmer of the Party's presence. In the past, Party rules, branches, and members have, to some degree, been present in these spacesbut rules may have gone unimplemented, branches may have been dormant, and members may have given dominance to other identities. 
Today, in the social sphere, the CCP is using new rules, institutions, and campaigns to encourage members and nonmembers, CCP organisations and non-CCP organisations, to create and apply new and dynamic ways to facilitate or enforce 'Party leadership' (党的领导). This is more than an increase in the intensity of Party activity or of efforts to implement previously semi-dormant rules. It also involves new approaches and mechanisms that will potentially change the relationships between different actors and between the institutions that shape their behaviour.

An interesting example is the employment of full-time 'Party building guidance officers' (党建工作指导员 PBGOs) in NGOs. In some cases, their salaries are paid by the government through service-purchasing projects. In Anhui province in 2017, 20 PBGOs 'took up residence' in 61 provincial-level NGOs, dividing their time between their host NGOs. In Chengdu, over 700 PBGOs and 'Party building liaison officers' (党建工作联 络员 PBLOs)-which mainly observe and report on the NGO's Party activities-have been stationed in NGOs around the city. In June, Anhui's provincial Social Organisation General Party Committee (SOGPC) began evaluating the work of its first 'batch' of PBGOs as they came to the end of their initial tenure. The evaluations included a combination of qualitative appraisals and quantitative indicators covering 13 aspects of PBGOs' work, and were carried out jointly by the NGOs themselves and the SOGPC. Two points here are notable. First, while 'Party building' in general remains a fuzzily-defined concept, in Anhui there is an attempt to quantify and describe good NGO 'Party building work'. While Party building in NGOs is not new, the attempt to better enforce, oversee, and facilitate accountability of it is novel and merits attention. Second, this type of model potentially changes the dynamics of 'Party building' inside the NGOs involved. The introduction of a PBGO as a full-time addition to the staff of an NGO to guide its Party building does not replace the existing requirement in the Party's own Charter that any 'social organisation' with three or more full Party members already belonging to it should establish a Party branch (党支部). But while the members of a Party branch should in theory come from within the NGO itself, in both of the above cases the PBGOs are introduced from outside the NGO.

Charter that any 'social organisation' with three or more full Party members already belonging to it should establish a Party branch (党支部).

Another less overt example of a shift in the relationship between Party, government, and NGOs is the institutionalisation of demands on the latter to become involved in poverty alleviation. Vice-minister Zhan, in a recent speech to the China 
Charity Alliance, described poverty alleviation as the 'natural duty' (天职) of Chinese charities (China Social Organisations Public Service Platform 2019). The Charity Law's definition of 'charity', in contrast, is relatively broad and does not create such imperatives. Charities-a concept introduced by the Charity Law itself in 2016-are not a legal form of organisation in their own right. They are one of three types of 'social organisation' that are registered with, and managed by, the government and which have successfully applied for charitable status accreditation. Even when accredited they may-but often do not-go on to gain the right to engage in public fundraising. Considering both this broad definition and the restriction of the right to fundraise to a privileged few, the notion that poverty alleviation is a natural duty of charities is surprising and potentially troubling for many. Charities and other NGOs working in different fields will likely come under pressure to spend significant time and resources on poverty alleviation. This clear indication of how the central government interprets 'charity' is already in some areas being replicated and institutionalised at the local level. In the provincial-level city of Tianjin, for example, the government has issued orders for poverty alleviation to be incorporated into social organisation evaluations and credit data systems for all social organisations.

But this is not only a narrowing of the notion of 'charity', it is also an example of 'Party leadership' in action. In late 2018, a central inspection tour spent over a month examining the Ministry of Civil Affairs' work on 'the poverty alleviation battle' (脱贫攻坚战 PAB). The findings were reported to CCP General Secretary Xi Jinping, who made an 'important speech' and other remarks. Following this, the Ministry's Party Group held a meeting attended by all civil servants of the Ministry and its live-in commission for discipline inspection. The Party Group Secretary and Minister, Huang Shuxian, spoke at the meeting to stress the importance of the Ministry fulfilling its PAB duties: '[We] need to have the pressure trickle down to each level; all departments and bureaus need to set up poverty alleviation and inspection result-based rectification small leadership groups' (Party Building in Social Organisations 2019). Huang's speech demonstrates the need in the Ministry to heed the Party's PAB-related top-down demands, which extend across and down throughout the civil affairs system, including its social organisation management departments, and charity sector promotion and social work departments.

In practice, participation in $\mathrm{PAB}$ is already being incorporated into NGO and NGO project evaluations contracted out by the civil affairs ministry and bureaus. In some localities only projects under the $\mathrm{PAB}$ label count. In other words, if an NGO has alleviated poverty, but not done so within the Party- 
recognised $\mathrm{PAB}$, it will fail to gain points in its evaluation. Evaluations are important as they help to determine the NGO's access to government-funded projects, its public credibility, and-in some localities-its ability to apply for charitable accreditation and the right to fundraise. This is a practical blending of a high-profile campaign of the Party and the role in society of all types of NGOs. It is also an important example of how, by combining all of the processes described here, 'Party leadership' might be more effectively enforced.

Viewed as a whole these processes present a clearer picture of what is meant by a "path with Chinese characteristics for social organisation development' (中国特色社会组织发展道 路). However, what is not yet clear is how NGOs will continue to use their own agency in this changing context. With new vocabularies, new compulsion to come out of the 'grey', new imperatives to abide by the 'spirit' of legislation, and new dynamics in their interactions with the Party, NGOs will need to adapt. Some, no doubt, will internalise each of these new processes and perhaps come to look more like 'people's organisations' (人民团体) than 'social organisations' (社会组 织). But others may adapt in ways that enable them to retain some autonomy while making that autonomy less apparent to outside onlookers. 